\title{
Osvrt na umjetničku filozofiju Friedricha Nietzschea
}

Božica Dragišić*

bozica.d@gmail.com

Ivan Šstak**

isestak@ffrz.hr
UDK: 1 Nietzsche, F. W.

7.01

Pregledni rad / Review

Primljeno: 23. lipnja 2017. Prihvaćeno: 5. srpnja 2017.

Friedrich Nietzsche je vrlo dojmljiva osoba suvremene filozofije. Njegova misao usmjerena je na kritiku europskog čovjeka oblikovanog metafizičkim naslijeđem. S druge strane, on pokušava, u vlastitom suočavanju sa zbiljnošću, donijeti novu perspektivu mišljenja. Ono se u intuitivnom ophođenju sa svijetom želi ozbiljiti po uzoru na umjetnički zadatak. Cilj je filozofa iskristalizirati svoju umjetničku bit, pri čemu stvaralački mora postaviti nove vrijednosti. Iznimna neprozirnost Nietzscheova djela, filozofije koja se više skriva negoli otkriva, onemogućuje sustavni prikaz njegova filozofijskog opusa. Razlog tomu jest Nietzscheov upravo nesustavni i pjesnički neiskaziv odnos sa zbiljnošću u skladu s razmatranjem nemogućnosti njezina oblikovanja pojmovnim kategorijama koje bi se istinito odnosile na njezinu bit. Svjestan nemogućnosti oslonca na metafiziku, kojoj je pripisao jedino moralistički $i$ vrijednosno-sustavni odnos sa svijetom, pokušava Nietzsche iznijeti diskurs budućeg razumijevanja u znaku intuitivnog prepoznavanja i opravdanosti paradoksa koji se nalazi u heraklitovskoj biti života, čime ujedno iznalazi umjetničku potvrdu života kao velebne igre gradeće-razarajućeg pra-temelja.

Ključne riječi: Dioniz, dionisko, Apolon, apolonsko, antička tragedija, tragična spoznaja, umjetnost, igra, prevredovanje vrijednosti, volja za moć, vječni povratak jednakoga.

\footnotetext{
* Božica Dragišić, mag. fil., Fakultet filozofije i religijskih znanosti Sveučilišta u Zagrebu; Dobriše Cesarića 28, HR-31000 Osijek.

** Izv. prof. dr. sc. Ivan Šestak, Fakultet filozofije i religijskih znanosti Sveučilišta u Zagrebu, Jordanovac 110, HR-10000 Zagreb.
} 


\section{Uvod}

U slučaju Nietzschea, nameće se pitanje mogućnosti govora o relevantnosti njegove misaone koncepcije u okviru filozofije kao discipline, a opet je njegova pojava nezaobilazna u povijesti suvremene filozofije. Što se tiče njegovih vlastitih pretenzija, namjera mu nije bila da bude filozof, čak i sam sebe nerijetko naziva »lakrdijašem«. Ipak je, kao glasnik jednog mučnog doba u kojem se dvotisućljetni moral europskog čovjeka, oblikovan metafizičkim i religijskim naslijeđem, našao u stupici nihilizma, preuzeo na sebe ogroman zadatak preinačenja dotadašnje filozofske problematike po uzoru na umjetnički zadatak. Također je "povukao« hrabar i samotan potez kojim se kritički i negacijski obrušio na cjelokupan metafizički, znanstveni, kulturni i religijski sustav zapadnoeuropske tradicije. Kada govorimo o umjetničkoj filozofiji Friedricha Nietzschea, prvenstveno moramo imati na umu da tu nije govor o umjetnosti kao fenomenu prisutnom u zbilji koja se da ocjenjivati pomoću filozofskih pojmova. On već na početku svog stvaralaštva umjetnosti daje povlašten položaj te je dovodi u neposrednu vezu sa životom promatrajući filozofiju, znanost, moral i kulturu pod optikom umjetnosti, a umjetnost pak pod optikom života.

U kombinaciji osobnog odnosa s Richardom Wagnerom, čija orkestralna simfonija odgovara antičkoj tragediji, sa simbolikom Apolona i Dioniza čija se mistična borba i jedinstvo odvijaju u duhu Schopenhauerove volje i predodžbe uz primjesu heraklitovske igre, započinje Nietzsche svoj put impozantnog filozofsko-pjesničkog izričaja prožetog aforizmima, emotivnim nabojima i oštrim izjavama. Ako bismo ga proučavali sa stajališta intelekta ne bismo ga mogli istinski razumjeti jer se on sam ne rukovodi pojmovnim određenjima vlastitih uvida. Promatrajući njegovo djelo više kao glazbenu kompoziciju riječi, rečenica i odlomaka pruža nam svojevrsno olakšanje (ponekad ekstatično) jer se tada krećemo u području intuicije ili, Nietzscheovim rječnikom, u području dioniskog.

U njegovim djelima je pak prisutna stalna patnja jer za ono što je Nietzsche htio izraziti jezik nije dovoljan, samo privremen. Počevši s dva proturječna principa koja se uzajamno prožimaju u antičkoj tragediji koja je prikaz svjetske igre pra-temelja sa samim sobom, iako s odstupanjima, koncept u kojem je stvaralaštvo koje pretpostavlja umjetnost slika samog kozmičkog stvaranja, Nietzschea ne napušta. Tijekom svih razdoblja svoga filozofiranja, on je kritičar i razaratelj idealizma. Ujedno pretendira k postavljanju novih vrijednosti u maniri umjetničkog stvaralaštva koje se ne uznemirava proturječjem što stoji u osnovi života kao takvog. Završni obris njegove filozofije ogleda se u odnosu volje za moć i vječnog povratka jednakog čija se svjetotvorna igra opravdava u slici boga Dioniza ili pak u slici samog Nietzschea i duboke tragedije vlastita završetka. 


\section{Umjetnost kao organon filozofije}

Središnja je ideja Nietzscheova stvaralaštva u tome da je umjetnost organon filozofije. Takvo poimanje umjetnosti nalazi se već u njegovom mladenačkom spisu Rodenje tragedije iz duha glazbe te ga ono prati u svim razdobljima njegova života i misaonog stvaralaštva. Spomenuto djelo iskazuje vjernost geniju Richarda Wagnera i njegovoj glazbenoj drami koja po unutrašnjem ustrojstvu odgovara antičkoj tragediji. Nietzsche se u to vrijeme smatrao filozofskim pandanom Richardu Wagneru

»čiji se estetski demon također nije zadovoljavao i iscrpljivao $u$ jednom rodu, te je nadošao na ideju sveukupnog umjetničkog djela (Gesamtkunstwerk), na onu simboličku predstavu u kojoj se multimedijalno i sinestezijski želio inscenirati cijeli Wagner.$^{1}$

Bez obzira na njegovo kasnije osobno i filozofsko udaljavanje od Wagnera, to djelo, prema Finkovim riječima, postavilo je glavne odrednice daljnjem umjetničkom nastojanju njegove filozofije. ${ }^{2}$

$\mathrm{U}$ početku je Nietzsche jedino $\mathrm{u}$ fenomenu antičke tragedije vidio istinsku narav zbiljnosti, a tragično pjesništvo i glazba su mu značili ključ biti svijeta ${ }^{3}$ te se u umjetničkom događaju rođenja tragedije iz duha glazbe ogledao pra-događaj rođenja u mnoštvo »likova« razloženog svijeta iz kaotičnog pra-temelja. Ono »tragičko« razumijeva Nietzsche kao kozmički princip. ${ }^{4}$ Pod utjecajem Arthura Schopenhauera, čiju je volju i predodžbu Nietzsche ujedinio u protunapetost dionizijskog i apolonskog načela, naziva on svoj prvijenac artističkom metafizikom koja stoji u oštroj opreci s dotadašnjim filozofskim, kulturnim i religijskim nasljeđem europskog čovjeka:

»Već u proslovu Richardu Wagneru postavlja se umjetnost - a ne moral - kao prava metafizička djelatnost čovjeka; u samoj se knjizi višestruko vraća izazovna postavka da je postojanje svijeta opravdano samo kao estetski fenomen. $\aleph^{5}$

Nietzscheova estetika označuje način na koji se stvari uopće vide u smislu otvaranja mogućnosti za razvoj »diskursa života« u filozofijskom mišljenju pri izbjegavanju metodologije monolitno-logičkog sustava. ${ }^{6}$ Temeljne spoznaje Nietzcheove filozofije imaju uvijek formu prosvjetljenja, one izviru iz simbolima bliskog temeljnog iskustva te se iskušavaju u području moći pjesništva i mišlje-

\footnotetext{
1 Peter SLOTERDIJK, Mislilac na pozornici. Nietzscheov materijalizam, prev. Ranko Sladojević, Sarajevo, Veselin Masleša, 1990, 79-80.

${ }^{2}$ Usp. Eugen FINK, Nietzscheova filozofija, prev. Branko Despot, Zagreb, Znaci, 1981, 20.

${ }^{3}$ Usp. isto.

${ }^{4}$ Usp. isto, 25.

${ }^{5}$ Friedrich NIETZSCHE, Rodenje tragedije, prev. Vera Čičin-Šain, Zagreb, Matica hrvatska, 1997, 15.

${ }^{6}$ Usp. Samir ARNAUTOVIĆ, Nietzscheovo »antiprosvjetiteljstvo« i prosvjetiteljski obrat, u: Damir BARBARIĆ (ur.), Nietzscheovo nasljeđe, Zagreb, Matica hrvatska, 2002, 29.
} 
nja, ili štoviše, Nietzsche je rastrgan njihovim antagonizmom. ${ }^{7}$ Nietzscheova nadarenost je, kako ističe Peter Sloterdijk, dvostruka:

»Nietzscheovi talenti uistinu nisu skup odijeljenih sposobnosti: među njima nema nikakve stvarne razdjelnice, niti puke koegzistencije. Štoviše, u ovom autoru svaki put djeluje jedna snaga kroz drugu, tako da on nije bio, kao toliki umjetnici, ujedno pisac i glazbenik, pjesnik i filozof, producent i teoretičar itd. nego glazbenik kao pisac, pjesnik kao filozof, producent kao teoretičar. On nije činio jedno pored drugoga, on je uvijek obavljao jedno tako što je činio drugo. ${ }^{8}$

\subsection{Apolonsko i dionizijsko kao umjetnički nagoni}

U viđenju tragedije Nietzsche započinje s uvidom »da je dobitak za 'estetsku znanost' ako je došlo do 'neposredne sigurnosti zora', da je daljnji razvoj umjetnosti vezan uz dualizam onog apolonskog i dioniskog, slično kao i rasplod uz dvojstvo spolova «. ${ }^{9}$ Nazive apolonsko i dionizijsko Nietzsche uzima od starih Grka koji su svoje nazore na umjetnost iskazivali likovima iz svoga svijeta bogova. ${ }^{10}$

»Uz njihova dva božanstva umjetnosti, Apolona i Dioniza, veže se naša spoznaja da u helenskom svijetu postoji silna oprečnost - u pogledu podrijetla i ciljeva - između likovne umjetnosti, apolonske, i nelikovne, glazbene umjetnosti kao one Dionizove; ta dva tako različita nagona gibaju se usporedno, većinom u otvorenu neslaganju jedan s drugim i uzajamno se izazivajući na vazda nove, snažnije plodove da bi u njima perpetuirali borbu one opreke koju zajednička riječ 'umjetnost' samo prividno premošćuje....«11

Apolon kao bog jasnoće, svjetla, sklada i ljepote, radosne slike, simbolizira obrazovani nagon brinući o obliku i izgledu dok određuje mjeru i postavlja granicu, ${ }^{12}$ a nasuprot njemu Dioniz kao bog glazbe što mami, uzbuđuje i oslobađa sve strasti, upućuje na ono kaotično bezmjerno i neprilagodljivo, na spolni nagon, tamu, noć. Dioniz osigurava jačinu i dubinu osjećaja te potiče želju za razaranjem. ${ }^{13}$ Dva načela pokazuju se, dakle, kao metafore za međusobno suprotstavljene umjetničke nagone Grka, kao antagonizam između slike i glazbe. ${ }^{14}$ "Nietzsche navodi za razjašnjenje protuigre takovih umjetničkih nagona 'fiziologijsku' opreku ljudskog života; on preskače u psihologiju. « ${ }^{15}$ Ta opreka se vraća u analogiji sa snom i opijenošću.

\footnotetext{
${ }_{7}$ Usp. Fink, Nietzscheova filozofija..., 26-27.

${ }^{8}$ Sloterdijk, Mislilac na pozornici..., 79.

${ }^{9}$ Fink, Nietzscheova filozofija..., 27.

${ }^{10}$ Usp. Nietzsche, Rodenje tragedije..., 27.

${ }^{11}$ Isto.

${ }^{12}$ Usp. Mihailo ĐURIĆ, Niče i metafizika, Beograd, Prosveta, 1984, 252.

${ }^{13}$ Usp. isto.

${ }^{14}$ Usp. Fink, Nietzscheova filozofija..., 27.

${ }^{15}$ Isto.
} 
»Lijep privid u svjetovima sna, u stvaranju kojih je svaki čovjek potpun umjetnik, pretpostavka je svekolike likovne umjetnosti, a - kao što ćemo vidjeti - i važne polovice poezije. Uživamo u neposrednom razumijevanju lika, svi oblici nam govore, nema ničega ravnodušnog ili nepotrebnog. I uz najintenzivniju životnost te zbiljnosti sna svejednako nas još prožima osjećaj njezina privida...«16

San je nesvjesna slikotvorna snaga čovjeka. Time što stvara slike, likove, figure, on je stvaralačka vizija.

Apolon ne stvara samo svijet slika ljudskog sna, nego stvara i svijet slika onoga što čovjek uzima kao zbiljsko. Otuda Nietzsche iz psihologijskog tumačenja sna »izlazi« u metafiziku. Apolon predstavlja principium individuationis, on je stvoritelj pojavnog svijeta. Svijet odijeljenosti bića, njegova mnogostrukost i raskomadanost, zapleten je u privid bez čovjekova znanja. Svijet, ukoliko zapravo jest, u sebi je jedan nerazlikovan život. Mnogostrukost je privid svejednog. ${ }^{17}$ Isto vrijedi za opijenost, za ono dionisko. Ponajprije se ima u vidu kao ljudski element opijenosti u kojem se čovjek nalazi u ekstatičkom stanju istupanja izvan sebe u istovjetnost sa svime što ga okružuje. ${ }^{18}$

»Pod utjecajem narkotičkog napitka, o kojemu svi iskonski ljudi i narodi govore u himnama, ili pod silinom nadolazećeg proljeća što sladostrasno prožima cijelu prirodu bude se ti dioniski porivi uz porast kojih ono subjektivno iščezava do potpuna samozaborava... « ${ }^{19}$

U tom, dioniski prožetom zanosu rob postaje slobodnim čovjekom, »lome se sve krute, neprijateljske ograde što su ih nužda, samovolja ili 'drska moda' postavili među ljude. Sada uz evanđelje svemirskog sklada, svatko se sa svojim bližnjim ćuti ne samo sjedinjen, pomiren, stopljen, nego kao jedno, kao da se Majin veo pokidao pa mu tek krpice lepršaju pred tajnovitim Pra-Jednim «. ${ }^{20}$

Dionisku zanesenost Nietzsche odmah preokreće u kozmičko:

»Čovjek više nije umjetnik, postao je umjetničkim djelom; najpunije zadovoljenje slasti onog Pra-Jednog, tu se srsi opojnosti objavljuje umjetnička silina cijele prirode. $\ll^{21}$

Dimenzija dioniskog je prije mistički naslućena nego što je pojmovno dohvatljiva i određena. Nietzsche ga proglašava svojevrsnim estetičkim pra-fenomenom, iskonskom umjetničkom pojavom. Rođenje tragedije započinje uvidom u apolonsko i u dionisko, no premda je dionisko pra-temelj umjetničkom stvaranju, Nietzsche ih ne odvaja, štoviše, on otvoreno ističe nužnost njihova povezivanja. ${ }^{22}$ Ta dva načela su od početka upućena jedno na drugo pa je samo zato i bilo moguće njihovo konačno udruživanje u tragediji. ${ }^{23}$

\footnotetext{
${ }^{16}$ Nietzsche, Rodenje tragedije..., 28.

${ }^{17}$ Usp. Fink, Nietzscheova filozofija..., 28.

${ }^{18}$ Usp. isto.

${ }^{19}$ Nietzsche, Rodenje tragedije..., 30.

${ }^{20}$ Isto, 31.

${ }^{21}$ Isto.

${ }^{22}$ Usp. Đurić, Niče i metafizika..., 250-251.

${ }^{23}$ Isto, 253-254.
} 


\subsection{Tragičko razumijevanje svijeta}

Grčka tragedija je nastala iz dioniskih ditiramba, tragičkih korova pjevanih u slavu bogu Dionizu. U tragediji živi i održava se velika religijska ideja iskupljenja svijeta kroz patnju i bol. U svojoj jezgri ona je bila samo tragički kor, a kasnije mu je uspostavljena scenska radnja pridavanjem dijaloga čime je završen proces »objektivacije« grčke tragedije kao umjetničkog djela. Nietzscheovo oduševljenje tragedijom činilo je njezino svojstvo kazališne igre - izvođački karakter. U izvedbi ona ne priznaje podjelu na autora, djelo i publiku, već u njoj sudjeluje cjelokupna publika koja je svjedok drame kao događaja. Njezina umjetnost se odvija time što svi prisutni ljudi zajedno plešu i pjevaju. ${ }^{24}$ Kor, $u$ čijoj su pjesmi bezgranično sudjelovali svi prisutni u ekstatičkom stanju jedinstva, izvorno predstavlja dioniski životni princip.

Predmet tragedije je Dioniz, tragički junak koji se iz ekstatičkog stanja pojavljivao na sceni $u$ apolonskom trenutku dramske radnje čiji je pak premet bio njegovo stradanje i patnja. Time se Dioniz pod vodstvom kora uz klikćuće odobravanje i potvrđivanje svog stradanja kao pojedinačnog boga kojeg su rastrgali Titani, posvećen uništenju, vraćao u vlastiti bez-konačni, dioniski temelj iz kojega se pojavio kao apolonski lik vizije tragičkog junaka. Dioniz predstavlja simptom uzlaska i silaska životnog temelja.

Osnovna spoznaja tragičkog razumijevanja svijeta jest da su sva konačna obličja (apolonsko) samo "privremeni valovi u velikoj bujici života « ${ }^{25}$ (dionisko). Propast konačnog bića nije njegovo uništenje već je samo povratak u bezlični životni temelj iz kojega je sve pojedinačno izašlo. Iz tog razloga tragički pathos nije pesimistički već naprotiv, tragički osjećaj života jest »jedno kazivanje Da životu, klikćuće pristajanje još i na strahovito i stravično, na smrt i propast «. ${ }^{26}$ Život i smrt nisu odvojeni jedno od drugoga već postoje kao osnovno proturječno jedinstvo pra-temelja.

\section{3. Život kao umjetnička igra}

Svijet, biće u cjelini jest igra. Pojava individuacije, mnogostrukosti pojedinačnosti bića u različitosti onoga stravičnog i lijepog jest lijepi privid u smislu tragičke vizije, ${ }^{27}$ odnosno »umjetnička igra, koju volja, u vječnoj punini svoje naslade, igra sama sa sobom « ${ }^{28}$

Schopenhauerova volja i predodžba, temeljno ontologijsko razlikovanje koje Nietzsche preuzima u svoju artističku metafiziku, označava gibanje, stvara-

\footnotetext{
${ }^{24}$ Usp. isto, 259.

${ }^{25}$ Fink, Nietzscheova filozofija..., 34.

${ }^{26}$ Isto, 21.

${ }^{27}$ Usp. isto, 37.

${ }^{28}$ Nietzsche, Rodenje tragedije..., 109.
} 
lačko događanje. Kao što umjetnik proizvodi svoje djelo, tako pra-temelj igra svijet proizvodeći mnoštvo upojedinjenih bića. Slikovitije rečeno: stvaralački proces umjetnika odraz je izvornog stvaralačkog procesa kozmičkog života. Umjetnost je ontologijski simbol vladavine bitstvujuće biti bitka. Jednako kao što umjetnik iskušava izbavljenje $u$ djelu umjetničkog stvaranja, kao što je $u$ lijepom prividu preobražena patnja i ono stravično,

»tako zadobiva stvaralački temelj svijeta na lijepom prividu mnogostrukih likova konačnog bića privremeni mir prebivanja - ali pratemelj ne igra samo u gradnji, nego i u razaranju; u svo bivanje stvari već je bačeno sjeme propasti, u svoj nasladi rađanja i ljubavi vije i naslada smrti, uništenja «. ${ }^{29}$

Pojava je umjetnički produkt umjetničkog nagona pratemelja, sredstvo kojim on sam sebe susreće, nužnost samosvijesti pratemelja. ${ }^{30} \mathrm{U}$ tragičkoj igri, opreci apolonskoga i dioniskoga, događa se samoprikaz svjetske igre bitka. Tim središnjim uvidom u prispodobi igre Nietzscheova filozofija seže natrag do Heraklita. U tragediji prepoznaje Nietzsche isti dioniski temelj koji nam prikazuje

»igrajuću izgradnju i rušenje individualnog svijeta kao isticaj jedne pre-naslade, na sličan način, kao kad tamni Heraklit svjetotvornu snagu uspoređuje s djetetom što igrajući se razbacuje kamenčiće i hrpu pijeska oblikuje i opet kamenčićima razbija.$^{31}$

U pojmu igre prepoznaje Nietzsche prvu jednadžbu za »nevinost bivanja« s onu stranu dobra i zla. ${ }^{32}$

\subsection{Sokrat i teorijski čovjek kao suparnik tragičke mudrosti}

Suprotnost dioniskom umjetničkom je barbarsko dionisko koje bi, ako se ne bi »praznilo « u apolonskom, završilo rasplinuto u neobuzdanosti i prekomjernosti te bi postalo mješavina pohote i okrutnosti. Kada bismo pak apsolutizirali apolonsko, kada bi ono postojalo samo za sebe, ne bi bilo istinski apolonsko. Budući da bi izgubilo svoju samosvojnost koju posjeduje putem dioniskog, pretvorilo bi se u optimistički nauk: sokratizam. ${ }^{33}$ Nietzsche ono sokratsko ponajprije vidi u Euripidovom protjerivanju kora sa scene te u vrednovanju dijaloga (apolonskog), čime logički nagon pobjeđuje onaj mitski:

»Optimistička dijalektika bičem svojih silogizama protjeruje glazbu iz tragedije, tj. ona razara bit tragedije koja se dade interpretirati jedino kao manifestacija i slikovni prikaz dioniskih stanja, kao vidljiva simbolizacija glazbe, kao svijet sna dioniske opijenosti. ${ }^{34}$

\footnotetext{
${ }^{29}$ Fink, Nietzscheova filozofija..., 37.

${ }^{30}$ Usp. isto, 37-38.

${ }^{31}$ Nietzsche, Rodenje tragedije..., 107.

${ }^{32}$ Usp. Fink, Nietzscheova filozofija..., 38.

${ }^{33}$ Usp. Đurić, Niče i metafizika..., 254.

${ }^{34}$ Nietzsche, Rodenje tragedije..., 99.
} 
Sa Sokratom i sokratskom umnošću dolazi kraj tragičkog razdoblja. Počinje razdoblje uma i razvitak teoretskog čovjeka čime nastaje ogroman svjetski gubitak: ${ }^{35}$

»opstanak gubi u neku ruku otvorenost za tamnu noćnu stranu života, gubi mitsko značenje o jedinstvu života i smrti, gubi protunapetost individuacije spram prajednog životnog temelja, postaje plitak, sputan pojavnim, postaje 'prosvijećen'«. ${ }^{36}$

U liku Sokrata prepoznaje Nietzsche cenzuru od najvećeg povijesnog značenja. On mu važi kao unesrećeni Grk par excellence, određen monsturoznim nedostatkom instinktivne mudrosti.

»Kod Sokrata je bila izražena samo jedna strana duha, ali ova na ekscesivan način: logičko-racionalni moment. Sokrat nije imao nikakav mistički organ. On je specifični ne-mistik. Ali on je bio opsjednut nagonom da sve preobrazi u mislivo, logičko, umno. Sokrat se javlja tako u aspektu jednog demona uma, čovjeka, u kojem se sva žudnja i sva strast preobrazila u volju za racionalnim raščlanjivanjem i ovladavanjem bića.« ${ }^{37}$

\section{Metafizički moral i prevrednovanje vrijednosti}

Razdoblje nakon djela Rodenja tragedije iz duha glazbe mijenja poziciju Nietzscheova filozofiranja. U intimnom smislu to znači Nietzscheovo traganje za vlastitim izrazom. Usredotočujući misao na samoga čovjeka, polazeći od kojega interpretira čitav svijet, započinje Nietzsche vlastiti misaoni put na kojemu kao »slobodan duh« eksperimentira s naslijeđem metafizičke i kršćanske tradicije, ali i s vlastitim prethodnim uvidima. Religija, metafizika i moral su u Nietzcheovoj kritici neodvojivo povezani, i to na način transcendencije vrijednosti koja je ništa drugo do samootuđeni ljudski nabačaj koji stoji u službi slabosti i siromaštva života. Nakon Platonove interpretacije metafizika se kreće $\mathrm{u}$ horizontu udvostručavanja svijeta (onog nadosjetilnog, istinskog, pravog koji na bitkujući način jest, te onog osjetilnog i prolaznog koji mjeru bitka dobiva jedino putem onoga što jest, a da je samo po sebi prividno i lažno).

»Izvorno ontologijska diferencija između pravog i nepravog bića postaje 'teologijskom diferencijom', razlikom između relativnog i apsolutnog, između stvorenih stvari i stvarajućeg Boga. ${ }^{38}$

Tako ono "pravo « što na bitkujući način jest zadobiva lik bića najviše razine. Svijet se mijenja u biće Boga u čijem se beskonačnom i svemoćnom karakteru

\footnotetext{
${ }^{35}$ Usp. Fink, Nietzscheova filozofija..., 35.

${ }^{36}$ Isto.

${ }^{37}$ Isto, 35-36.

${ }^{38}$ Isto.
} 
izražava bitak svijeta koji pak vrijedi kao ono »dobro« naprosto te stvarima daruje mjeru bitka.

»Ideja istinskog svijeta, ideja zapravog bića, apsolutnog, Boga za njega je najopasnija opasnost čovještva; jer time ono provodi sudbonosno odvraćanje od zbiljnosti - i provodi to odvraćanje u ime istine. Nagon istine postaje tako jezivim zasljepljenjem čovjeka. On ga dovodi dublje u bludnju nego li ma kakvo naivno povjerenje u osjetila. « ${ }^{39}$

Metafizika se u svom posjedu istinitosti bitka tumači moralno: pojavljuje se kao kretanje života $u$ kojemu se dokumentiraju »procjene vrijednosti« $\mathrm{i}$ to one koje guše i slabe život. Pitanje samog bitka prikriva se kod Nietzschea pitanjem o vrijednosti. ${ }^{40} \mathrm{U}$ kršćanstvu je on vidio samo povijesni otisak nametnute vrijednosti bitka. Ono predstavlja vrednovanje cijelog zapadnog istumačenja bitka koje sve ono osjetilno, zemaljsko tumači kao privid u svjetlu ideja, odnosno u svjetlu nadzemaljskog, pravog, istinskog onostranog svijeta pojmovno dohvatljivog. S Bogom je mišljena transcendencija vrijednosti, u njemu čovjek preobražava svoje najviše vrijednosti te im daje osobnu egzistenciju, ${ }^{41}$

»no ako vodeće vrijednosti potječu iz nemoći, tada je rezultat i bog na križu, onostrani bog koji životne nagone i instinkte proklinje kao 'grijeh'; on garantira tada svetost i neuzdrmljivost, transcendenciju vrijednosti što niječu život. Smrt Boga znači otuda za Nietzschea prije svega ukidanje transcendencije vrijednosti, otkrivanje vrijednosti kao ljudskih ostvarenja.« ${ }^{42}$

Filozofija sa svojim usmjerenjem prema smislu započinje zabludom i završava u zabludi jer se može potvrditi isključivo vlastitim nametnutim vrijednosnim pravilima. Tim unutrašnjim razornim procesom, igrajući po vlastitim pravilima igre, dospjela je u nihilizam. U pokušaju prevrednovanja vrijednosti valja imati na umu da, ukoliko je nihilizam »redukcija bitka na razmjensku vrijednost $«,{ }^{43}$ činjenicu

»da za Nietzschea nisu iščezle vrijednosti tout court, nego vrhovne vrijednosti, sažete upravo u najvišoj vrijednosti par excellence, Bogu. No tako pojmu vrijednosti nipošto nije oduzet smisao, nego se ova - kao što je dobro uvidio Heidegger - oslobađa u svojoj vrtoglavoj potencijalnosti. Naime, samo tamo gdje nema završne i 'prekidajuće', blokirajuće vrhovne vrijednosti, dakle Boga, vrijednosti se mogu razviti u svojoj istinskoj naravi, pretvorljivosti i neodređenoj promjenljivosti, odnosno procesualnosti. «4

\footnotetext{
${ }^{39}$ Isto.

${ }^{40}$ Usp. isto, 18.

${ }^{41}$ Usp. isto, 170.

${ }^{42}$ Isto, 18.

${ }^{43}$ Gianni VATTIMO, Čitanka, prev. Mario Kopić, Zagreb, Antibarbarus, 2008, 74.

${ }^{44}$ Isto, 75.
} 


\subsection{Istinitost privida}

Ako uopće možemo govoriti o Nietzscheovoj ontologiji, onda bi ona na prvi pogled izgledala kao preobražaj dotadašnje ontologije koja pravo biće misli kao izvanvremenski bitak, a ono nepravo, prividno kao vremenito. Tako izgleda da Nietzsche bitku suprotstavlja bivanje, onom općem konkretno, »duhu« tijelo i sve to s obrnutim ontologijsko-moralnim vrednovanjem. No njegova borba protiv vrijednosti zapravo znači uopće borba, protiv razlikovanja između pravog i nepravog, protiv osnovne diferencije koju daje metafizika. Nietzsche promiče indiferenciju opstanka koja se ne uznemiruje izmišljenom razlikom koja pak promiče osnovnu nevinost i naivnost života. Time otklanja ontologijsku razliku između »istinskog« i »prividnog« svijeta. Prestaje shvaćati privid $\mathrm{u}$ suprotnosti s istinom (shvaćenih u metafizičkom smislu), pri čemu priznaje apsolutno pravo privida na potpunu samostalnost i jedinu realnost nasuprot zabludama metafizičkih $»$ istina ${ }^{45}$ Tijekom povijesti zapadnjačke metafizike, ono što je održavalo neku »istinu« jest uvijek bila »vjera u istinu«, koja pak nije nikakav dokaz za postojanost nečega što bi bilo istinito, time apsolutno i mjerodavno, već je značila moć koju je neka perspektiva posjedovala da bi se što duže održala, da bi vladala stvarnošću, posjedovala neku sigurnost u neprestanoj mijeni. »Naša religija, moral i filozofija oblici su dekadencije čovjeka. - Protugibanje: umjetnost. $\aleph^{46}$

Platon se nikako nije mogao pomiriti s iskrivljavanjem istine u umjetnosti budući da je njezino neopozivo svojstvo proizvođenje "privida«, no kod Nietzschea "'privid' znači ovdje realnost još jednom, samo u izboru, ojačanju i korekturi«. ${ }^{47}$ Privid umjetnika je drukčiji i zbiljskiji nego onaj pojmovnog mišljenja, jer umjetnik "probija uvijek ponovno kroz sav privid do strahovite realnosti koja privid potrebuje kao sredstvo utjehe «. ${ }^{48} \mathrm{U}$ poznom periodu Nietzcheove filozofije tragična, dioniska umjetnost postaje opet organonom njegova filozofiranja. Njezina mudrost se sada pak ogleda u promišljanju volje za moć i vječnog povratka jednakoga, što ne »probija fenomene, pojave da bi došlo do nekog stražnjeg svijeta koji bi ih omogućavao, već misli fenomene u dubini surove filozofije bez iluzija, otvorene strahovitoj ljepoti dvostrukosti opstanka. $^{49}$

\footnotetext{
${ }^{45}$ Usp. Đurić, Niče i metafizika..., 219-221.

${ }^{46}$ Friedrich NIETZSCHE, Volja za moć. Pokušaj prevrednovanja svih vrijednosti, prev. Ante Stamać, Zagreb, Mladost, 1988, 378.

${ }^{47}$ Isto, 408.

${ }^{48}$ Fink, Nietzscheova filozofija..., 182.

${ }^{49}$ Usp. isto.
} 


\section{Promjena opstanka u stvaralački samo-bitak čovjeka}

Kako smo već naznačili, događaj samoobezvrijeđivanja metafizike, religije i morala kao spoznaje samootuđenja čovjeka znači nadolazak nihilizma. Radikalnom kritikom i prevrednovanjem vrijednosti Nietzsche nanovo otvara mogućnost za »jedan novi, strahovit i jezivo lijep, 'tragički' pogled na svijet $«{ }^{50} \mathrm{Raz}$ mišljajući o vrednovanju, smatra Nietzsche da su ona u krajnjem smislu životni programi, odnosno nabačaji uz koje se sam život veže, postavljajući sebi zadaću. Ona su povijesni pothvati u budućnost. Kao putanje ljudskih puteva ona čine životni pokušaj. Takav program nije jasan, on se mora povijesno dosegnuti. Kršćanstvo, njegov naslijeđeni moral i metafizička filozofija u svojoj osnovi su nihilistički pokreti: životne tendencije koje smjeraju Ničemu, makar one ono Ništa maskiraju pojmom Boga. Govoreći o Bogu kao Ničemu, Nietzsche govori o nihil u summum ens. Ne samo teološki pojmovi, već i oni kozmologijski, poput smisla i jedinstva, koji povijesti pripisuju neki cilj, vode u nihilizam.

Nihilizam poricanjem metafizički mišljenog istinskog svijeta sam postaje božanskim načinom mišljenja oslobođenog podložnosti idealima. Da se ne bi održavao u dekadenciji, pesimizmu slabosti, čovjek mora na sebe preuzeti zadaću da postane uništavatelj metafizičkih i moralnih vrijednosti. Dok se slobodan duh poigravao s idealima poričući i sumnjajući u njih, novi čovjek, odnosno nadčovjek mora postati »razaratelj«idealizma.

»Sva ona ljepota i uzvišenost što smo ih pozajmili zbiljskim i zamišljenim stvarima zahtijevam da se vrati kao vlasništvo i proizvod čovjekov: kao njegova najljepša apologija. Čovjek kao pjesnik, kao mislilac, kao Bog, kao ljubav, kao moć: o kraljevske li njegove darežljivosti kojom je obdario stvari da bi sam osiromašio sebe i stao sebe osjećati bijednim! Najveća njegova dosadašnja nesebičnost bila je to što se divio i obožavao a znao tajiti sebe, što je baš on bio taj koji je stvorio ono čemu se divio. ${ }^{51}$

Prevlada li se nihilizam, nastaje novo shvaćanje čovjekove izvorne biti: stvaralaštvo. Što neki čovjek više stvara, to je on izvornije pjesnik, umjetnik, mislilac i time je na višoj razini među ljudima. Negacijom ontologije ne poznaje Nietzsche dimenziju bića koja bi bila na višem stupnju bivstvovanja, »više bitkujuća « jer su sve stvari samo fikcija, prividne tvorevine iza kojih stoji moć, kvantum snage, volja za moć. Jedini poredak prema razini koji opstoji jest onaj u zemlji ljudi, vazda prema stvaralačkoj snazi koja se iskazuje u čovjeku ili u narodu (kakav je bio onaj grčki). ${ }^{2}$

Promjena opstanka iz samootuđenja u stvaralačku slobodu koja zna samu sebe jasno je prikazana u Zaratustrinoj prispodobi o tri preobrazbe u Nietzscheovu pjesničko-filozofskom djelu Tako je govorio Zaratustra: »Pokazat ću

\footnotetext{
${ }^{50}$ Isto, 185.

${ }^{51}$ Nietzsche, Volja za moć..., 75.

${ }^{52}$ Usp. Fink, Nietzscheova filozofija..., 194.
} 
vam tri preobrazbe duha: kako duh postaje devom, deva lavom i najposlije lav djetetom. ${ }^{53}$ Deva je simbol opstanka u načinu bitka veličine. U njezinu liku obitava čovjek strahopoštovanja koji se otuđuje od sebe sama klečeći pred uzvišenošću Boga i ćudorednih zakona, voljno noseći velike terete.

„Što je teško - tako pita duh koji je voljan da nosi, tako pada na koljena, poput deve, i traži da ga dobro natovare. Što je najteže, vi, junaci - tako pita duh koji je voljan da nosi - da to naprtim na sebe i da se radujem svojoj snazi. Nije li ovo: poniziti se, kako bi se uvrijedila vlastita oholost. Dopustiti da sjaji vlastita ludost, kako bi se narugala vlastitoj mudrosti. ${ }^{54}$

Deva označava čovjeka pod teretom transcendencije koji ne uzima stvari olako i želi životne zadaće na kojima se potvrđuje. U vlastitoj veličini strahopoštovanja i poslušnosti želi se pokoravati idealnim stvarima i podvrgavati se životnom smislu koji mu je dosuđen. Okružen čvrstim sustavom vrijednosti voljno se potčinjava zapovijedi: »Ti trebaš. $\aleph^{55}$ Kaže Nietzsche:

»Duh koji je voljan da nosi prima na sebe sve što je najteže: poput deve koja, natovarena, žuri u pustinju, žuri i on u svoju pustinju. Ali u najsamotnijoj pustinji zbiva se druga preobrazba: tu postaje duh lavom, želi da se dograbi slobode i da bude gospodar u svojoj vlastitoj pustinji.⿲丿氵

Preobrazbom deve u lava prikazana je propast idealizma time što se iz istinoljubivosti događa samoukidanje morala. Čovjek u slici lava i svojoj posljednjoj borbi s idealizmom spoznaje vlastito prijašnje samootuđenje.

»On tu traži svog posljednjeg gospodara: hoće da mu postane neprijatelj, njemu i svojem posljednjem bogu, s velikim se zmajem želi boriti za pobjedu. Tko je veliki zmaj, što ga duh ne može nazivati više gospodarem i bogom? 'Ti si dužan' zove se veliki zmaj. Ali duh lava kaže 'ja hoću'... Braćo moja, zašto je potreban lav u duhu? Zašto nije dovoljna tegleća životinja, koja se odriče i koja je puna strahopoštovanja. Lav ne može još stvoriti nove vrijednosti: ali može sebi stvoriti slobodu za novo stvaranje - to može snaga lava. ${ }^{57}$

Sloboda lava, odnosno sloboda nijekanja idealističkih iluzija samootuđenja, to znači transcendencije vrijednosti, morala i metafizičke stvari, po sebi još nije dovoljna za stvaralačko htijenje novog nabačaja vrijednosti. Htijenje nove volje u lavu još uvijek nema istinsku opuštenost stvaralaštva. To ima tek treća preobrazba duha, dijete.

"Sebi prisvojiti pravo na nove vrijednosti - to je najstrašnije prisvajanje za duh koji je voljan da nosi i koji je pun strahopoštovanja. Doista, za nj je to grabež i stvar grabežljive zvijeri... Ali kažite mi, braćo moja, što to još može dijete,

\footnotetext{
${ }^{53}$ Friedrich NIETZSCHE, Tako je govorio Zaratustra, prev. Danko Grlić, Zagreb, Mladost, 1967, 23.

${ }^{54}$ Isto.

${ }^{55}$ Fink, Nietzscheova filozofija..., 87.

${ }^{56}$ Nietzsche, Tako je govorio Zaratustra..., 23-24.

${ }^{57}$ Isto, 24.
} 
što nije mogao ni lav? Zašto mora grabežljivi lav postati još i dijete? Dijete je nevinost i zaborav, stalno otpočinjanje, igra, kotač, koji se iz samog sebe okreće, prvi pokret, sveto kazivanje Da. $\ll^{58}$

Kazivanje Da se odnosi na igru stvaranja koju zahtijeva duh u svojoj konačnoj preobrazbi koja je ekvivalentna djetinjoj nevinosti bivanja. Izvorna bit stvaranja odnosi se na slobodu koja stvara nove vrijednosti i nove svjetove vrijednosti nagovarajući se u metafori igre. U slobodi se događa konačna metamorfoza njezine biti - igre. U tom novom prostoru bivanje jest sloboda, a sloboda jest stvaralaštvo (naspram dosuđene konačnosti slobode u duhu težine). Time se vraćamo na prvijenac u kojem Nietzsche stavlja igru u središte razumijevanja (pristajući uz Heraklita) i time interpretira osnovicu dioniskog. U ovom govoru Zaratustre igra

»još nije puna dioniska igra svijeta, nije igra pratemelja koji izgrađuje i razara pojavni svijet, ona je ovdje razumljena kao igra čovjekovog ocjenjivanja vrijednosti, kao igrački nabačaj svjetova vrijednosti. ${ }^{59}$

U igri djeteta, umjetnika, odnosno nadčovjeka zrcali se igra pratemelja sa samim sobom, što je izraženo u konceptima volje za moć i vječnog povratka jednakog, na vrlo sličan način odnosa apolonskoga i dioniskoga.

\section{2. Život kao volja za moć}

Nietzscheovo iskustvo bitka izraženo je u intuitivnom konceptu: volji za moć. Glede kritike metafizike, treba istaknuti da Nietzsche opširno, ali loše i površno opisuje Platona i Kanta, donoseći o njima sumaran sud. U sveprisutnoj nejasnoći njegovih općenitih sudova načelno vrijedi da su Nietzscheove misli uvijek dublje od njegovih obrazloženja, naznaka i dokaza. Nietzsche sluti novu dimenziju mišljenja, no sam je ne može jasno iznijeti na vidjelo. Zato valja iznova napomenuti da se on kreće u ruhu umjetničkog prikaza svijeta, povijesti i vlastite pozicije. Njegova misao je intuitivna te pokušava improvizirati, kako $\mathrm{s}$ nasljeđem metafizike na čijem tlu niče, tako i s vlastitim uvidima. ${ }^{60} \mathrm{Iz}$ tog mu razloga ne uspijeva sustavno razvijanje misli, budući da se intuitivno nalazi

»u pretpostavci da enigmatski karakter zbiljnosti nikada nije izraziv u jednom sistemu, da je život još uvijek labirintskiji, mnogoznačniji, tajnovitiji od sveg ljudskog poimanja - da nije samo istina žena što se teško dade osvojiti nespretnom nametljivošću filozofa, da je još više život sam žena, neprovidna, bestemeljna, nepojmljiva«. ${ }^{61}$

\footnotetext{
${ }^{58}$ Isto.

${ }^{59}$ Fink, Nietzscheova filozofija..., 88.

${ }^{60}$ Usp. isto, 183.

${ }^{61}$ Isto.
} 
Ako je ontologija kod Nietzschea poprimila formu filozofije vrijednosti, tada se volja za moć uspostavlja kao princip novog postavljanja vrijednosti. U sadržaj volje za moć Nietzsche stavlja cjelokupno postojanje, čak i ono organsko. Život i smrt, priroda, spoznaja, idejni nazori, društvena uređenja, čovjekov položaj u svijetu, smisao postojanja, filozofija sa svim svojim disciplinama, odnosi spolova, vlast istine, vrline, um, Boga, ukratko sve što jest - nije ništa do prikrivenija ili neskrivenija manifestacija volje za moć.

Volja za moć je zaokret prema promjeni opstanka u stvaralački samo-bitak čovjeka. Dok je smrt Boga, odnosno vrhunske vrijednosti, borba protiv onoga što bi htjelo biti iznad čovjeka, svojstvena svima jer smo u njoj svi jednaki, volja za moć je »biblija« stvaralačkog čovjeka pa prema tome i tema za njega određena. Također se u nacrtu volje za moć kao spoznaje i volje za moć kao umjetnosti na prikriven način izriče raščlamba na »metaphysica generalis« $\mathrm{i} »$ metaphysica specialis« (uspoređujući s Kantovom kritikom čistoga uma), utoliko što prva ima posla s bićem kao bićem, a druga s bićem kao prirodom, čovjekom i Bogom. ${ }^{62}$

"'Volja za moć kao spoznaja' nije, kako se često razumije, samo neka spoznajna teorija; ovaj odsjek sadrži Nietzscheovu negativnu ontologiju stvari. A napokon odsjek o umjetnosti nije drugo negoli njegova 'teologija', teologija bez Boga, to znači bez kršćanskog Boga kao stvoritelja svijeta, ali teologija koja opravdava opstanak kao estetski fenomen, u sjaju onog lijepog saznaje ono neokrnjeno svijeta, religija-umjetnost igrajućeg boga Dioniza. (...) Spoznaja volje za moć otpočinje spoznajom volje za moć $u$ spoznaji.«63

To znači da obično nazivanje nečega spoznajom ima za pretpostavku djelovanje volje za moć. Ona se nalazi u samom htijenju spoznaje kao nagon asimiliranja i nadvladavanja, čak i više od toga: sam proces spoznaje već stoji pod uvjetima volje za moć. Drugim riječima, ono što označavamo kao proces spoznaje nije samo organ mogućnosti spoznaje volje za moć već to jest volja za moć koja se, kao ono oblikujuće samog spoznavanja, ne može dohvatiti pomoću spoznaje. Takvo stajalište produkt je Nietzscheove filozofijske intuicije koja proizlazi iz otvorenosti za tijek bivanja, gradeći i razarajući život, za gibanje volje za moć. Jedino tragička spoznaja, odnosno znanje tragičke mudrosti "probija« tvorevinu moći (spoznaje). Ovdje Nietzsche shvaća spoznaju bića koja je jednom iskustvena, empirijska, a zatim i apriorna spoznaja koja oblikuje stvari pomoću kategorija. Nietzsche negacijski suprotstavlja aktivnost bivanja, uzgibanost i mijenu života svakoj konačnosti uobličenoj bilo u stvari, supstanciji, biću i bitku, odnosno onom ustrajnom. No pri tom zaključku on ne ostaje, ne zaustavlja se na osjetilnom, pri stvarima, njihovu odlaženju, dolaženju i promjenama. Njegova filozofija ne završava u pojedinačnom, prostorno i vremenski ograničenom. Nietzsche ne apsolutizira sferu konačnih stvari, već

\footnotetext{
${ }^{62}$ Usp. isto, 199.

${ }^{63}$ Isto.
} 
na nov način misli njihov temelj. Gibanje, aktivno bivstvovanje on razumijeva kao volju za moć, a ono vremenito (biti-u-vremenu) uopće kao vječni povratak jednakoga. Uz nadčovjeka, temeljni izrazi prevratničkog mišljenja: volja za moć i vječni povratak jednakoga nisu nešto što pred-leži danim stvarima nego ono što se objavljuje u mišljenju što »probija« privid i fikciju. Te dvije instance nisu »udomljene« u nekom onostranom svijetu, nisu mišljenje kao neka bit različita od pojave već čine bitstvujuću bit onog zemaljskog, prolaznog i konačnog. Time u Nietzscheovoj filozofiji nije riječ o stražnjem svijetu, već o vladavini svijeta samoga, velikoj igri opreka izgradnje i razaranja, uzlaska i silaska i onog vraćanja što sve stvari stavlja na kocku i »uvlači« u igru.

»Kod Nietzschea se prvi put u povijesti filozofije bitak razumije u događanju. ${ }^{64}$ Cjelokupna spoznaja se na isti način pokazuje u imanentnoj negaciji svakog smisla bivstvovanja. To upućuje, s obzirom da je ukinuta smislenost koja se ima dohvatiti u istini bitka, na aktivnost bivstvovanja i spoznaje, njihovu dinamičku moć.

»Sve Nietzscheove kritičke intencije imaju priliku da se realiziraju samo s obzirom na dinamičko shvaćanje spoznavanja, $\mathrm{u}$ kojem se postojanje neposredno dovodi u vezu s aktivitetom, koji se, zapravo, u bitnom izražava kroz spoznavanje... Aktivitet spoznaje, razumljen kao dinamika volje za moć, ovdje u prvi plan dovodi razumijevanje, odnosno izvorno Da-seinovo ophođenje sa svijetom, način njegova bivstvovanja u svijetu. « $^{65}$

Iz toga slijedi da i pri falsificiranju stvarnosti koje provode metafizika, logika, jezik, religija i moral, stoji volja za moć. Biologijska nužnost navodi intelekt da stvara pojmove, kategorije da bi neshvatljivo bivanje učinilo shvatljivim. Ono što jest je valovita životna bujica, struja bivanja. Spoznaja iskrivljuje zbilju pomoću laži sigurnosti nečeg što je ustrajno, supstancijalno, bilo da je stvar, supstancija, biće, Ja. Fikcija sama jest tvorevina volje za moć koja kao spoznaja »smiruje« tijek bivanja i laž podvrgava pojmu, a da svoje »nasilje« nad zbiljnošću zaboravlja vjerujući u samo-ostvarenost kategorijalnih pojmova kao realnih prodora u zbiljnost. ${ }^{66}$ Ako je svojstvo intelekta bitno falsificiranje, logično je da čovjek koji uspostavlja privid kategorija, kao falsificirajuće biće mora imati realnu pojedinačnu egzistenciju. No Nietzsche izbjegava posljedicu takva mišljenja: čovjek nije neka posljednja pojedinačnost, on je sam sebi fikcija. Ono što tvori fikcije jest život, volja za moć. Ona oblikuje fikcije intelekta jednako kao što oblikuje konačnu tvorevinu čovjeka. Kao što je u prvijencu Apolon oblikovao ne samo lijepi privid, već i privid individuacije, tako volja za moć stvara konačne likove u životnoj struji promjene i djeluje kao intelektualni falsifikator. Ona je »valovita protuigra centara snage i kvantuma volje koji se zgrušavaju, ali

\footnotetext{
${ }^{64}$ Arnautović, Nietzscheovo »antiprosvjetiteljstvo « i prosvjetiteljski obrat..., 26.

${ }^{65}$ Isto, 27.

${ }^{66}$ Usp. Fink, Nietzscheova filozofija..., 200-201.
} 
koji se isto tako ponovno rastvaraju kao i valovi mora.$^{67}$ Gibajući se u oprečnosti bitka i bivanja, suprotstavljajući bivanje bitku, donosi Nietzsche »novo« shvaćanje čija se najviša istina i moć objavljuju u vječnom povratku jednakoga, što znači da bitku utiskuje vrijeme i dinamiku. Na kraju odsjeka Volja za moć kao spoznaja zaključuje:

»Rekapitulacija: Bivanju pečatom utisnuti značaj bitka - to je najviša volja za moć... Da se sve nanovo vraća krajnje je približenje svijeta bivanja svijetu bitka: vrhunac promatranja... Spoznaja po sebi u bivanju nemoguća; Kao zabluda o samoj sebi, kao volja za moć, kao volja za obmanu. Bivanje kao izmišljanje, htijenje, nijekanje sebe, nadilaženje sama sebe: nipošto subjekt nego činjenje, postavljanje, stvaralačko, nipošto 'uzroci i učinci'. Umjetnost kao volja za prevladavanje bivanja, kao 'ovjekovječivanje', ali kratkovidno, već prema perspektivi: tako reći u malome ponavljajući tendenciju cjeline. Što pokazuje sav život promatrati kao usitnjenu formulu za sveukupnu tendenciju: stoga nova fiksacija pojma 'život', kao volja za moć. «68

Volja za moć kao umjetnost - shvaćanje umjetnosti i njezine zadaće u vremenu kada je Nietzsche objelodanio svoju kritičku filozofiju, nije puko ponavljanje već odavno prijeđenog puta svojega prvijenca. Ono sadrži mladenačke uvide, no donosi znatno produbljenje i proširenje, čak i bitno preinačenje početka te opravdava životvornost njegove filozofije. Umjetnosti Nietzsche više ne pristupa na način razumijevanja tragičke spoznaje u okviru grčke tragedije, već je tumači putem stvaralaštva umjetnika iz dioniskog estetskog stanja, u kojem se zrcali izvorno stvaranje volje za moć, u odnosu spram vječnog povratka jednakoga uz epifaniju boga Dioniza.

Rodenje tragedije komentira Nietzsche ovako:

»Koncepcija svijeta na koju se nailazi u pozadini ove knjige iznimno je tmurna i neugodna: među dosad poznatim tipovima pesimizma čini se da nijedan nije dosegao taj stupanj zloćudnosti. Nema tu protivštine istinita i prividna svijeta: postoji samo jedan svijet, a on je lažan, grozan, protuslovan, zavodljiv, bez smisla... Tako ustrojen svijet pravi je svijet... Da bismo došli do pobjede nad tom realnošću, tom 'istinom', to znači da bismo živjeli, potrebna nam je laž... Da je laž potrebna da bi se živjelo, i to se poklapa s tim strašnim i upitnim značajem postanka... Metafizika, moral, religija, znanost - na njih se ova knjiga obazire samo kao na različite oblike laži: uz njihovu se pomoć vjeruje u život. 'Život treba ulijevati povjerenje': zadaća, tako postavljena, silna je. Da bi je riješio, čovjek već svojom naravi mora biti lažljivac, nada sve drugo mora biti umjetnik. A to on i jest: metafizika, religija, moral, znanost - sve tek izrodi njegove volje za umjetnost, za laž, za bijeg od istine, za nijekanje istine. Sama sposobnost zahvaljujući kojoj on putem laži siluje istinu, ta umjetnička sposobnost čovjekova par excellence - njemu je zajednička sa svime što jest. ¿99 $^{69}$

\footnotetext{
${ }^{67}$ Isto, 204.

${ }^{68}$ Nietzsche, Volja za moć..., 298-299.

${ }^{69}$ Isto, 407-408.
} 
Za Nietzschea umjetnost nije nikakav fenomen prisutan u zbiljnosti na način kao što je prisutan umjetnik i njegovo djelo. Umjetnost, posebice u svom najvišem tragičnom obliku, ukazuje na vječni povratak jednakoga. Stvaralaštvo koje ju pretpostavlja, a to je volja za moć, jest pogled u srce svijeta: ono je prodor kroz sav vanjski privid stvari. Paradoks umjetnosti jest u njezinoj mogućnosti proboja kroz privid u unutrašnjost, a s iste strane i samo opravdanje tog privida. I to stoga što je privid umjetnosti stvarniji nego onaj pojmovnog mišljenja jer se u njemu ne objašnjava život, već opravdava i uopće omogućuje. U bezvremenskoj igri umjetnika zrcali se izvorna igra svijeta, gradeće-razarajuća igra djeteta koja je vječni povratak jednakoga. To pokazuje ujedno i duboku tragediju života kao i jedinu mogućnost da se ona izdrži u sjaju privida, u sjaju ljepote i vječnosti: u umjetnosti. ${ }^{70}$ Nietzsche otkriva da je umjetnost najvažnija i najmoćnija kulturna snaga. Privid koji ona proizvodi ima najveće značenje za ljudski život. ${ }^{71}$ »Istina je ružna: Umjetnost imamo zato da ne propadnemo $\mathrm{s}$ istine. $\aleph^{72}$ Umjetnost potvrđuje život jer idealizira osjetilne stvari i njihovu prolaznost. Ona takoreći proizvodi »privid privida« čime uzdiže život na viši stupanj.

»Ono bitno u umjetnosti ostaje njezino dovršavanje opstanka, njezina proizvodnja savršenosti i obilja; umjetnost je u biti potvrda, blagoslov, obožanstvenjivanje opstanka ... - Što znači pesimistička umjetnost?... Nije li to contradictio? - Da. - Vara se Schopenhauer kad stanovita djela umjetnosti stavlja u službu pesimizma. Tragedija ne uči 'rezignaciji'... - Prikazati strahote i upitne stvari već je instinkt moći i krasota u umjetnika: on ih se ne boji... Nema pesimističke umjetnosti... Umjetnost potvrđuje. (13 $^{73}$

\subsection{Dioniski svijet}

U simbolici Dioniza shvaća Nietzsche odnos volje za moć i vječnog povratka jednakog (kao odnosa apolonskog i dioniskog) kao i svjetsko-povijesne odluke preobrazbe čovještva po uzoru na nadčovjeka u nevinosti bivanja igrajućeg umjetnika. Time njegova filozofija poprima završni obris. Ovdje Nietzsche želi djelovati i to kao filozof djelovati, odnosno kao umjetnik želi stvaralački postaviti nove vrijednosti u službi volje za moć. Zato i sam sebe opisuje kao nužnost u povijesti filozofije, nužnost koju sama volja zahtijeva. Njegova filozofija volje za moć i sama želi moć, želi privremeni mir bivanja, no ne kao opće priznavanje, već kao životni nauk nekolicine viših tipova čovjeka.

U Zaratustri je Nietzsche pjesnički tematizirano čovještvo koje se odriče svih stražnjih svjetova i odlučno se okreće zemlji. Time ono spoznaje protur-

\footnotetext{
${ }^{70}$ Usp. Danko GRLIĆ, Ko je Niče, Beograd, Vuk Karadžić, 1969, 94-95.

${ }^{71}$ Usp. Đurić, Niče i metafizika..., 290.

${ }^{72}$ Nietzsche, Volja za moć..., 392.

${ }^{73}$ Isto.
} 
ječje i oprečnost kao »oca i regenta svih konačnih stvari, a istodobno beskonačnost sveg konačnog razumije u vječnom kružnom toku kružećeg vremena «. ${ }^{74}$ To čovještvo je nagovarano kao nadčovjek. Nietzsche koncipira nadčovjeka kao konkretnu zadaću samo-oblikovanja čovjeka. Takvo samo-obvezivanje kao protuteža raspuštenosti nihilizma, stoji sada u svjetlu njegovih filozofijskih pogleda u dubinu. ${ }^{75}$ Budući čovjek jest onaj hoteći čovjek čiji se bitak nalazi u volji za moć. Njegovo htijenje se sastoji u htijenju velike volje koji sebi i drugima daje obilježje; volja je uvijek činjenje nečega konačnim, no onaj hoteći istovremeno zna za konačnost svoga htijenja

»u otvorenosti za vječni povratak jednakoga zna on za posljednju besmislenost svog htijenja. Volja za moć i vječni povratak jednakoga stoje u neobičnom protuslovlju... koje ne dodiruje njihovu istinu, nego je upravo temeljna istina života, protuslovlje samog života. ${ }^{76}$

Budući čovjek jest dakle onaj koji stoji u zaptu tragičkog pathosa dvije protuslovne istine, onaj koji hoće, a istodobno znajući za uzaludnost svog htijenja čezne za bezobličnim temeljem života; koji je udomljen u dvostrukom području: u krčevini i prikrivanju. ${ }^{77}$

Pod voljom za moć misli Nietzsche na gibanje koje se u neku ruku ukrućuje u stvarima, likovima, figurama i oblicima. Ona proizvodi pojedinačno biće: kozmički princip opreke i razdvajanja, ono što pra-jedan, bujajući život cijepa u konačne likove. Istodobno, ona je i princip njihova nemira, međusobne borbe i otimanja za moći u kojem se one nadjačavaju i stupnjuju. Kao što oblikuje konačne likove, volja za moć ih ujedno i negira. Ono beskonačno prisutno u i na svakom konačnom jest vječni povratak jednakoga. ${ }^{78} \mathrm{U}$ istini vječnog povratka jednakoga svaki lik se razumije kao opetovanje,

»zadobiva njegova novost i povijesna jednokratnost karakter svevremenog; na jednokratnoj konačnoj stvari sijeva vječnost svijeta, ona iščezava u neku ruku $u$ dubini otvorenog bezdana vremena; $u$ vječnom ponovnom došašću misli se izvorno vladanje svijeta « ${ }^{79}$

Time je Nietzsche do kraja promislio dualizam nekadašnje artističke metafizike. Volja za moć i vječno ponovno došašće odnose se jedno spram drugoga kao apolonsko i dionisko tragične umjetnosti. Jedinstvo te dvostrukosti poima se u ime boga Dioniza. Dioniza Nietzsche shvaća ne više u odnosu s Apolonom, već s Raspetim.

»Dioniz nasuprot 'Raspetomu': tu eto imate protivštinu. Nije to diferencija s obzirom na mučeništvo - ono ima samo drugi smisao. Sam život, njegova vječ-

\footnotetext{
${ }^{74}$ Fink, Nietzscheova filozofija..., 209.

${ }^{75}$ Usp. isto.

${ }^{76}$ Isto, 210.

${ }^{77}$ Isto.

${ }^{78}$ Usp. isto, 211.

${ }^{79}$ Isto.
} 
na plodnost i ponovno vraćanje uvjetuje muku, razdor, volju za zatiranje... U drugom slučaju patnja, 'Raspeti kao Nedužni', slovi kao prigovor ovome životu, kao formula njegove osude. - Pogodit će se: problem je to u smislu patnje: da li kršćanski smisao, da li tragičan smisao...? U prvom slučaju treba to biti put $\mathrm{k}$ blaženu bitku, u potonjem pak bitak slovi kao dovoljno blažen da opravda svu silu patnje. - Tragičan čovjek potvrđuje i najtrpkiju patnju: dovoljno je za to jak, pun, bogotvoran. - Kršćanski niječe i najsretniju sudbinu na Zemlji: dovoljno je slab, siromašan, razbaštinjen, da u svakom obliku pati još za života... Dioniz razrezan na komade obećanje je u život: a on se vječno nanovo rađa i iz razaranja vraća kući.« ${ }^{80}$

Dioniz je jedinstvo volje za moć kao apolonske tendencije i vječnog povratka jednakoga kao dioniske dubine vremena na svim konačnim stvarima. Vječnim povratkom jednakoga mišljena je nova koncepcija svijeta.

"Svijet opstoji; nije on ništa što postaje, ništa što prolazi. Ili čak: on postaje, on prolazi, ali nikada nije počeo postojati i nikada prestao prolaziti - on se održava u obojemu... « ${ }^{81}$

Upravo ovdje se izriče osebujno ostajanje svijeta u kojem vječnost prisustvuje svoj prolaznoj mijeni; sve stvari u svom vremenitom prolazu imaju ujedno svjetski karakter vječnosti.

Zapravo je u znaku boga Dioniza Nietzsche sabrao svoje prvotno uviđanje o umjetnosti kojemu se od samog početka divio kao moćnom pokretaču umjetničkog stvaranja. Dioniz, koji znači potvrđivanje života u njegovoj vječnoj igri građenja i razaranja, svoje jedino opravdanje nalazi u umjetnosti. Nietzsche odlučno ističe da umjetnost ništa ne osuđuje niti odbacuje, naprotiv ona zauzima apsolutno potvrdan stav prema svijetu i životu u cjelini. Ona čak uživa u onome ružnom i neskladnomu, prihvaća ih u cjelini kao dio života te ima sposobnost preobraziti ružnu istinu u sjaj i ushićenje. Ona izbavlja mračnu stranu života u sjaj privida. Odnositi se umjetnički, odnosno dioniski prema svijetu i životu znači pustiti svemu što jest slobodu da bude jer ionako ništa nije stalno, a sve se nanovo vraća. Okosnica Nietzscheova filozofiranja je proturječnost, a u umjetnosti je on našao spas iz te proturječnosti. Zato želi usmjeriti filozofski zadatak na umjetnost, želi filozofa koji će stvaralački postaviti nove vrijednosti bez opterećenosti nasljedstvom metafizike, kao onoga koji nema cilj niti pokušava dokazati neku istinu. Time želi otvoriti nov horizont umjetničkog promišljanja koje improvozira sa svime što život nosi bez osuđivanja i moralističkog vrednovanja u skladu sa životom kao voljom za moć. Nietzsche želi filozofiji napuštanje teorijskih nastojanja u radikalnom preinačenju filozofskog uma po uzoru na umjetničko stvaranje. ${ }^{82}$

\footnotetext{
${ }^{80}$ Nietzsche, Volja za moć..., 486.

${ }^{81}$ Isto, 490.

${ }^{82}$ Usp. Đurić, Niče i metafizika..., 320.
} 


\section{Zaključak}

Umjetnost Friedricha Nietzschea načelno znači nove horizonte misaonog istraživanja zbiljnosti, novi diskurs jedne svjetski otvorene egzistencije neopterećene naslijeđenim formama filozofske tradicije. No ipak, Nietzsche izrasta na tlu metafizike, ipak se on na neki način suočava sa zbiljnošću na način metafizike, premda ona bila u znaku negacije i u pokušaju oslobođenja od nje. Problematika koju on donosi odgovara nacrtu zapadnjačke metafizike. Vezano uz kritiku metafizike Nietzsche poglavito osuđuje tendenciju apsolutiziranja onoga što on vidi kao samo jednu perspektivu unutar mnogih. Ono pak što izražava temeljnu intenciju njegova mišljenja oslobođenu metafizičke forme jest ne-metafizička misao igre. Tijekom čitava razdoblja Nietzscheova stvaralaštva prisutna je tajnovita dimenzija igre. U prvom razdoblju ona je nagovarana u heraklitizmu igrajućeg svjetskog pra-temelja, a kasnije kao igra djeteta $\mathrm{i}$ umjetnika.

Igra postaje za Nietzschea ključ poimanja univerzuma, ona je ujedno i bit novog čovještva, ukoliko je on ekstatički otvoren za vladajući svijet volje za moć i vječnog povratka jednakoga. Ondje gdje se ima u vidu igra svijeta i gdje intuitivno mišljenje probija apolonsku varku konačnosti i progledava u smjeru gradeće-razarajućeg života, može se čovjek u svojoj umjetničkoj produktivnosti osjećati kao onaj koji je upušten u kozmičku igru rođenja i smrti svih stvari s onu stranu dobra i zla. Igru sve-moći, život gradnje i razaranja imenuje Nietzsche Dionizom, igrajućeg čovjeka imenuje nadčovjekom. ${ }^{83}$ Nietzsche svojom filozofijom donosi novi ideal, no ne i novi program čime i potvrđuje nesustavan odnošaj sa zbiljnošću. U svojoj tajnovitoj, pojmovno neiskazivoj umjetničkoj filozofiji za cilj je imao dokinuće teorijskih nastojanja filozofije i htio je samu misao u duhu filozofa-umjetnika izraziti kao stvaralačku s ciljem uzdizanja života.

Nesumnjivo je Nietzsche svojim proročkim i pjesničkim stilom filozofiranja ostavio dubok trag u povijesti filozofije. Njegov utjecaj proteže se na različita područja kulture i filozofije 20. stoljeća. Izvršio je golem utjecaj na važne filozofe poput Heideggera, Foucaulta, Derridu, Jaspersa, Deleuzea i drugih važnih osobnosti našeg vremena. Njegova je misao imala izravan utjecaj i na razvoj plesne kulture 20. stoljeća, no to je već druga tematika. Ipak on nije imao za cilj dovršenje svoje filozofije, premda ju je često nastojao teorijski opravdati. Mi se u čitanju njegovih djela ne možemo oteti dojmu da je čitava filozofija Friedricha Nietzschea potaknuta njegovim intimnim životnim iskustvima. On ne vodi borbu samo s nasljedstvom filozofijske tradicije, njegova borba jest borba oprečnih osjećaja jednog života. I toj perpetuiranoj borbi Nietzsche je posvetio čitav svoj život u neovisnosti jednog umjetnika koji se, umjesto traženja izbav-

$\overline{{ }^{83} \text { Usp. Fink, Nietzscheova filozofija..., } 230 .}$ 
ljenja u onome već prijeđenom putu, »poigrao « s vrijednostima koje su oblikovale čitavu zapadnjačku povijest. Slikovito rečeno, Nietzscheova filozofija jest drama, kazališna igra jednog života. Između oprečnih životnih osjećaja: patnje i naslade, apolonskog i dioniskog, estete i umjetnika, volje za moći i vječnog povratka jednakoga, razaratelja i stvaratelja stoji Nietzsche kao slobodan duh, kao Zaratustra, kao nadčovjek, naposljetku kao Dioniz. Umjetnost života Friedricha Nietzschea filozofiji dopušta stvaralački napor misli nošen u vrtlogu intuicije, a ne prosječno (ili natprosječno) sljedbeništvo već domišljenih obrazaca, a čime je pak u povijesti filozofije pokazao originalnost i neustrašivost. Zaključno bismo mogli reći da je, neovisno o nemogućnosti dokazivanja njegova nazora na svijet, Nietzsche opravdao sebe kao umjetnika i svoju filozofiju kao umjetnost. 


\section{Božica Dragišić* - Ivan Šestak*** \\ Reflection on the Artistic Philosophy of Friedrich Nietzsche}

Summary

Friedrich Nietzsche is a very impressive figure of modern philosophy. His thought is directed to the critique of the European man shaped by a metaphysical heritage. On the other hand, he tries, in his own confrontation with reality, to bring a new perspective of philosophical thought. In its intuitive approaching of the world it intends to actualize itself as an artistic task. The goal of the philosopher is to crystallize his artistic being wherein he must creatively set new values. The considerable vagueness of Nietzsches's work, a philosophy that hides more than it reveals, makes it almost impossible to represent his philosophical opus in an organic way. The reason for this is just Nietzsche's unsystematic and poetically unutterable relation to reality in accordance with the consideration of the impossibility of formulating it in conceptual categories that would really refer to its essence. Aware of the impossibility of relying on metaphysics, to which Nietzsche attributed only a moralistic and value- systematic relationship with the world, he tries to introduce the discourse of future understanding in the form of intuitive recognition and justification of the paradox lying in the heraclitean essence of life, in which he, at the same time, grounds the artistic confirmation of life as a grandiose game of construction and devastation of the primordial ground.

Key words: Dionysus, dionystian, Apollo, apollonian, Greek tragedy, tragic knowledge, art, game, revaluation of values, will to power, eternal recurrence of the same.

(na engl. prev. James Corkery)

\footnotetext{
* Božica Dragišić, mag. phil., Faculty of philosophy and religious studies of the University of Zagreb; Address: Dobriše Cesarića 28, HR-31000 Osijek, Croatia; E-mail: bozica.d@gmail.com.

** Ivan Šestak, PhD, Assoc. Prof., Faculty of philosophy and religious studies of the University of Zagreb; Address: Jordanovac 110, HR-10000 Zagreb, Croatia; E-mail: isestak@ffrz.hr.
} 